\title{
A influência do conceito de felicidade da poesia arcaica grega na literatura sapiencial judaica após o cativeiro babilônico
}

\section{The Influence of the Concept of Happiness of the Archaic Greek Poetry on the Jewish Wisdom Literature after the Babylonian Captivity}

\author{
Milton Luiz Torres \\ Centro Universitário Adventista de São Paulo, Engenheiro Coelho, São Paulo / Brasil \\ miltntorres@gmail.com
}

Resumo: Este artigo apresenta uma comparação de aspectos do conceito de felicidade na poesia arcaica grega com a literatura sapiencial judaica após o cativeiro babilônico, com o objetivo de estabelecer a relação de uma com a outra. Para tanto, analisa a tensão existente entre sabedoria convencional e subversiva nas duas literaturas, dando especial atenção a sete dimensões relativas à felicidade: a moderação, o conhecimento de si, o controle das paixões, o respeito aos próprios limites, o tipo de morte, o esquivar-se à fiança e, finalmente, a saúde. A vertente predominante da literatura sapiencial judaica é aquela expressa nos livros de Provérbios, Eclesiástico, Sabedoria e Salmos de Salomão. São os livros de Jó e Eclesiastes que requerem explicação devido a sua filiação aos apotegmas da sabedoria subversiva, incomum nos círculos judaicos. A conclusão de que essa vertente tenha se originado do contato com os gregos tem duas vantagens explanatórias: dá algum tipo de suporte à suposição tão comum entre os historiadores do judaísmo de que os processos de helenização de Israel tiveram início bem antes do século III, período geralmente apontado como época do desencadeamento de tais processos, e propõe uma solução ao menos provisória para a misteriosa incursão de uma vertente não consuetudinária na literatura sapiencial judaica.

Palavras-chave: literatura sapiencial; poesia arcaica grega; judaísmo. 
Abstract: This paper presents a comparison of aspects of the concept of happiness in Greek Archaic Poetry with the Jewish Wisdom Literature after the Babylonian captivity, in order to establish the relationship between both. In order to do so, it analyzes the tension between the conventional and the subversive wisdom in the two literatures, paying particular attention to seven dimensions related to happiness: moderation, self-knowledge, control of the passions, respect for one's own limits, avoiding to offer a surety for a debtor, and finally, health. The predominant strand of Jewish wisdom literature is the one expressed in the books of Proverbs, Ecclesiasticus, Wisdom and Psalms of Solomon. But the books of Job and Ecclesiastes require explanation because of their affiliation to the apothegms of a subversive wisdom that is unusual in Jewish circles. The conclusion that this strand originated from contact with the Greeks has two explanatory advantages: it gives some support to the assumption so common among historians of Judaism that the processes of the Hellenization of Israel began well before the third century, a period generally referred to as the epoch of the unleashing of such processes, and proposes a provisional solution to the mysterious incursion of a non-customary strand in the Jewish Wisdom Literature.

Keywords: Wisdom Literature; Greek Archaic Poetry; Judaism.

A antiga literatura sapiencial judaica tinha por foco a existência quotidiana e os temas práticos da vida, apresentando uma temática abrangente com linguagem provocativa. Embora fizesse parte da seção bíblica conhecida como "Escritos" e fosse tradicionalmente associada a Salomão, essa literatura é difícil de datar (GESE, 2003, p. 189-190), pois não faz referências a eventos históricos. O consenso dos estudiosos é que pertença ao período pós-exílico. Além dos livros canônicos de Provérbios (500 a.C.), Jó (600, 550 ou 300 a.C. $)^{1}$ e Eclesiastes ou Qohélet (300 a.C.), a literatura sapiencial inclui, ainda, os livros de Eclesiástico ou Siraque (200 a.C.), Sabedoria de Salomão (100 a.C.) e Salmos de

\footnotetext{
${ }^{1}$ Por causa de sua difícil datação, há estudiosos que defendem que o livro de $J o ́$ pertence a diferentes períodos de composição: o início do séc. VII, durante o período de Ezequias (ANDERSEN, 2015); meados do séc. VI, depois da queda de Jerusalém (TERRIEN, 2004) ou entre os sécs. IV e III, na era do segundo templo (FOHRER, 1956; GORDIS, 1978).
} 
Salomão (70 a.C.). Seu tom é inteiramente diferente do Pentateuco e dos livros proféticos, dando mais atenção ao indivíduo e à família.

De acordo com Borg (2001, p. 145-182), os livros sapienciais não pretendiam ter o estatuto de verdade revelada e, por isso, apresentam uma natureza dialética e dialógica, o livro de Provérbios contendo duas grandes coleções: de poemas sapienciais (1-9) e de provérbios individuais (10-30). Na primeira parte, apresenta-se o "caminho" como a metáfora central da vida. A sabedoria, símbolo do bom caminho, é personificada como a primogênita da criação e como antecedente para uma imagem feminina de Deus. Em contraste, a mulher adúltera, símbolo do mau caminho, é personificada como antagônica à sabedoria, mas sem referência ao além-túmulo. Na segunda parte, os provérbios apresentam ilustrações práticas dos dois caminhos, cuja visão androcêntrica e homogênea foca a boa esposa como tipo de sabedoria e a prosperidade como resultado direto da mesma. Trata-se do que se convencionou chamar de "sabedoria consuetudinária" (CAMPOS, 1991, p. 154), segundo a qual a pobreza é o resultado da preguiça e só se necessita de senso comum para que se alcance a felicidade. É, por isso, um tipo de cosmovisão centrado no desempenho que põe ênfase na ordem do universo e que apresenta as dificuldades da vida como consequência do comportamento inadequado: ho dè phylássōn tòn nómon makaristós, "o que guarda a lei é feliz" (Pr. 29:18).

Os livros de Eclesiastes e Jó têm uma abordagem inteiramente diferente daquela de Provérbios, apresentando o que se convencionou chamar de "sabedoria subversiva". Em Jó, cuja profundidade Momigliano (1971, p. 81) compara à do Prometeu, de Ésquilo, e cuja autoria anônima Hartley (1988) liga aos sábios de Israel do período de Provérbios e Eclesiastes, patenteia-se a completa inadequação do senso comum como fonte de sabedoria para a vida prática. Da mesma forma, para o autor de Eclesiastes, a quem Campos (1991, p. 17) chama de "Nietzsche bíblico", a metáfora central é a da vida como ato de perseguir o vento, rejeitando a ideia de que o senso comum é a solução para os problemas da vida e apresentando uma nítida percepção das desigualdades sociais. O livro é marcado pelo tema da morte: sua inevitabilidade e aleatoriedade, em 
um "quase-ceticismo helenizado e nada ascético" (CAMPOS, 1991, p. 19). A sabedoria subversiva consiste, então, de uma abordagem radicalmente crítica do senso comum ou da sabedoria convencional sob três perspectivas: ensino pelo contraste, pessimismo (e depressão) e respeito pelo mistério da vida. Assim, Borg (2001) afirma que, em Eclesiastes, a morte é uma lição didática para a vida.

O autor da Sabedoria de Salomão, por sua vez, demonstra uma profunda devoção ao judaísmo e um exímio conhecimento da língua e cultura gregas (LANGE, 1936, p. 293). O livro pode ter recebido influência de diferentes sistemas da filosofia grega, incluindo de tradições desenvolvidas a partir de Tales, Pitágoras, Heráclito, Anaxágoras, Platão, estoicos e epicureus (HEINISCH, 1908). Seu conceito de beleza é basicamente platônico: a Sabedoria de Salomão reconhece a Deus como o "primeiro Pai” (genesiárkhēs) da beleza (13.3), descreve a sabedoria como mais bela do que o sol e as estrelas (7.29) e a deseja como noiva (8.2). De fato, a "escada mística" de Sabedoria de Salomão 4.17-19 faz lembrar a descrição do Banquete, 210a-212e (LANGE, 1936, p. 296-297). No entanto, o autor apresenta uma linguagem muito menos técnica do que a de Filo, por exemplo, e usa expressões corriqueiras mesmo quando lança mão dos conceitos da filosofia grega (7.22-24; 8.1, 24 ; etc.). A principal preocupação da Sabedoria de Salomão é com os aspectos éticos da religião e com o combate ao materialismo. Devido a sua condição de obra pseudepígrafa, o tipo de sabedoria defendido na obra é o mesmo posicionamento convencional de Provérbios, de que a correta observação de preceitos sábios deve levar o homem à felicidade.

O livro de Eclesiástico ou Sabedoria de Jesus, filho de Siraque, ou simplesmente Siraque, foi escrito originalmente em hebraico. O texto tendo sido presumivelmente escrito na Palestina, seu autor parece ter tido pleno conhecimento do mundo helenístico (Siraque 10.8). De fato, Siraque 39.1-4 descreve o sábio ideal como sendo uma pessoa que "pesquisa a sabedoria de todos os antigos" (sophían pántōn archaí̄n ekzētései), que "viaja pela terra de povos estrangeiros" (en gếi allotrí̄on ethnôn dieleúsetai) e que já entrou em contato com muitos reis. O prefácio da obra alerta que esta foi escrita para ajudar os que querem "andar na 
linha por meio de uma vida pautada pela lei" (epiprosthôsin dià tês ennómou biốseōs). Embora não se possa dizer, com certeza, que o prefácio fizesse parte do texto desde sua tradução para o grego, sua percepção consuetudinária do valor da sabedoria é confirmada no restante do livro.

Finalmente, os Salmos de Salomão apresentam a nação judaica dividida em duas classes: a dos justos, quase inteiramente formada pela facção dos fariseus à qual pertencia o autor; e a dos ímpios, isto é, os saduceus. $\mathrm{O}$ autor vê as catástrofes que se abateram sobre os judeus como o resultado direto de sua impiedade e da retribuição divina. Por isso, esses salmos pseudepigráficos (que exerceram pouca influência no desenvolvimento do judaísmo ou do cristianismo) são representantes clássicos da sabedoria convencional.

Por essas razões, Borg (2001) considera que os livros sapienciais apresentam, de forma admirável, os conflitos existenciais: (i) o conflito entre a religião de primeira e de segunda mão, (ii) o conflito entre o senso comum (sabedoria convencional ou consuetudinária) e a sabedoria alternativa (subversiva e misteriosa), (iii) os conflitos entre a teologia do Egito e a do êxodo, e (iv) os conflitos entre a teologia real e institucional e a teologia profética. Para Borg, os livros sapienciais antecipam, de modo adequado, as tensões existentes nas páginas do Novo Testamento. Minha sugestão é de que essa dicotomia nesses livros sapienciais se deve à influência que o conceito de felicidade da poesia arcaica grega teria exercido sobre eles, acrescentando-lhes a tensão existente entre sabedoria consuetudinária e sabedoria subversiva, especialmente em sua compreensão de que a felicidade não é automática, mas o resultado de um viver criterioso e prudente, embora particularmente sujeito às vicissitudes:

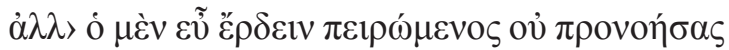

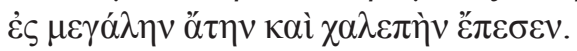

às vezes, aquele que se esforça para praticar o bem cai desapercebidamente em grande ruína e dificuldade. (SÓLON, Fragmento 13.7-8) 
Esta sugestão difere de outras explicações, como a de Bryce (1979), por exemplo, que prefere ver influências egípcias na literatura sapiencial judaica como um todo.

\section{A tensão entre a sabedoria convencional e a sabedoria subversiva na poesia arcaica grega}

De modo geral, depois de cristalizada sua tradição, os principais apotegmas dos sete sábios foram preservados em importantes documentos de épocas posteriores, entre eles um epigrama anônimo da Antologia palatina e o assim chamado Certame entre Homero e Hesíodo. $\mathrm{O}$ autor do epigrama anônimo não pretendeu ser exaustivo em sua exposição da tradição sapiencial grega. Simplesmente se referiu às principais máximas que imortalizaram Cleobulo de Lindos (séc. VI a.C.), pai da poetisa Cleobulina; Quílon (séc. VI a.C.), político espartano a quem se credita a invenção da Liga do Peloponeso; Periandro (625-585 a.C.), tirano de Corinto; Pítaco (650-570 a.C.), moderado reformador democrático de Mitilene, que dobrou a penalidade dos crimes cometidos sob a influência do vinho; Sólon (639-559 a.C.), herdeiro de Hesíodo, precursor de Ésquilo e elo de ligação entre os dois; Bias de Priene e Tales de Mileto (séc. VI a.C.), considerado por Aristóteles (Metafísica A 3, 983b20) como o fundador da física:

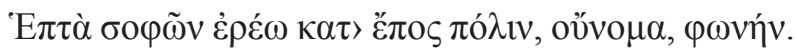

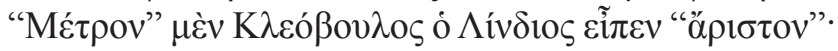

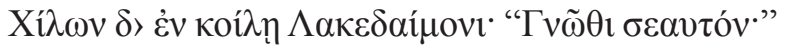

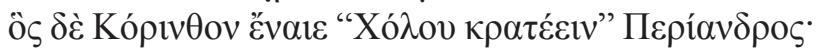

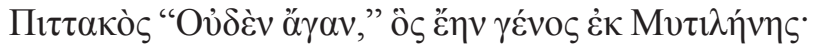

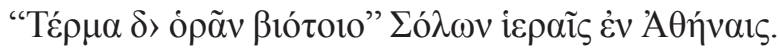

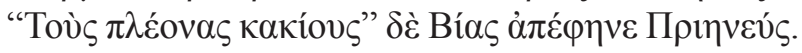

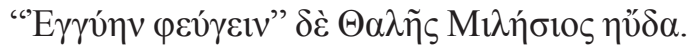

Revelarei a máxima, a cidade, o nome e a dicção dos sete sábios: Cleobulo de Lindos disse: "a moderação é a melhor coisa"; Quílon, porém, na côncava Lacedemônia: "conhece-te a ti mesmo"; Periandro, que morava em Corinto: "dominar a ira"; Pítaco, que era da tribo de Mitilene: "nada em demasia"; 
Sólon, na sagrada Atenas: "contemplar o fim da vida";

Bias de Priene declarou: "a maioria é má";

Tales de Mileto vaticinou: "fugir da fiança".

(Antologia palatina, 9.366)

O que não transparece, de forma nítida, no epigrama, mas que pode ser percebido na poesia arcaica grega ou nas máximas atribuídas aos sete sábios ou seus contemporâneos, é que o sine qua non da felicidade é, porém, o favor divino. O homem não tem, em si mesmo, poder algum para concretizar sua própria felicidade. Segundo Píndaro (Pítica 1.41), ek theôn gàr makhanaì pâsai, "pois dos deuses procedem todos os recursos". O elemento subversivo que contrasta com a concepção sapiencial tradicional é que a mera fidelidade aos deuses e a obediência a um conjunto determinado de preceitos originários da sabedoria divina e do senso comum não garantem a felicidade humana:

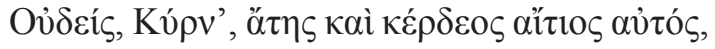

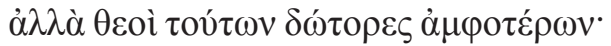

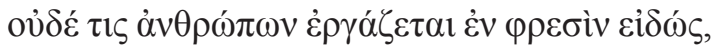

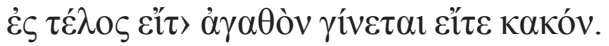

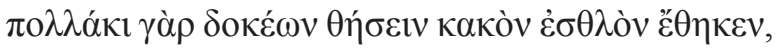

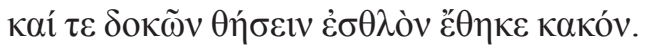

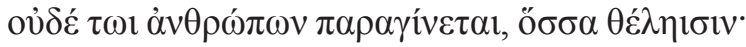

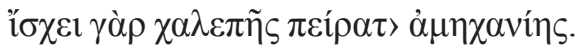

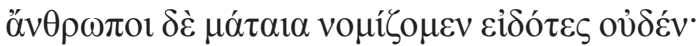

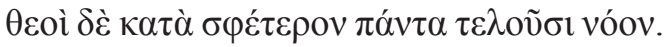

Nenhum homem é ele mesmo a causa de perda e ganho, Cirno; os deuses é que são os doadores tanto de um como de outro; nem ninguém labuta entre os homens, sabendo, em seu coração, se caminha para um bom ou mau fim;

pois, geralmente, pensando que alcançará o mal, alcança

o bem; e pensando que alcançará o bem, alcança o mal;

nem sucede ao homem aquilo que deseja,

pois seus desejos estão cheios dos limites da dificuldade irresistível;

nós, homens, praticamos coisas vãs, de nada sabendo, enquanto os deuses realizam tudo o que lhes vem à cabeça. (TEÓGNIS, 1.133-142) 
Mesmo o talento nato não é suficiente. Píndaro (Ístmica 6.1011; Olímpica 11.4), por exemplo, afirma que são ainda necessários esforço (pónos) e gasto (dapánē), estando implícita, nessa perspectiva, a possibilidade de fracasso. Enfatiza-se, assim, essencialmente, a participação incidental da ocasião ou circunstância (kairós) no mundo geral dos valores e da verdade. A passagem da prosperidade para o abuso da mesma pela arrogância ou violência e, então, para a ruína como consequência da punição divina, é própria do pensamento arcaico grego (DOYLE, 1970, p. 293-303). Há, de fato, uma consciência melancólica da mutabilidade da sorte humana: rhoaì d'állot'állai euthymiân te metà kaì pónōn es ándras éban, "várias circunstâncias em horas várias sucedem aos homens tanto acompanhadas de alegria quanto de sofrimentos" (PÍNDARO, Olimpica 2.33-34).

A intelecção expressa pelos sete sábios encontra reflexos na tensão existente entre o tradicional e o subversivo, que ocorre na poesia arcaica grega de modo geral. Na epopeia grega, especialmente na Ilíada, a felicidade masculina está vinculada ao nascimento nobre. A felicidade feminina se vincula ao marido (anếr) e à vida doméstica (oîkos), conforme sugere a Odisseia (6.180-182). Por isso, para Píndaro (Olímpica 9.100), tò dè phyâi krátiston hápan, "a constituição é sempre a mais forte". Nesse ambiente idealizado, a felicidade é expressa em termos materiais, pressupondo o respeito aos deuses, "pois, com Deus, a felicidade implantada nos homens é mais permanente": sỳn theồi gár toi phyteutheìs ólbos anthrốpoisi parmonốteros (PÍNDARO, Nemeana 8.17). Como se perceberá ao longo desta discussão, o primitivo ideal grego de felicidade aristocrática geralmente se voltava para o entretenimento de convidados, o cultivo de uma boa reputação e a fruição da saúde. Um fragmento de Sólon (semelhante ao dístico 2.1253-1254, de Teógnis) nos dá um claro vislumbre dessa perspectiva elitizada:

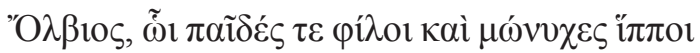

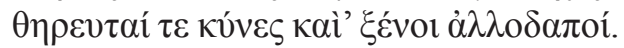

feliz é aquele que tem namorados carinhosos, cavalos de cascos sólidos, cães de caça e hóspedes de outras terras. (SÓLON, Fragmento 23.1-2) 
O ideal de felicidade da sabedoria judaica é consideravelmente mais frugal:

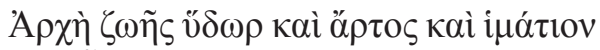

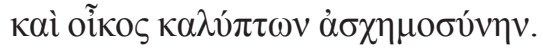 \\ o fundamento da vida é água, pão, roupa e casa \\ onde possamos ocultar nossas vergonhas.
}

(Siraque 29.21)

Como se percebe, coexistiram na poesia arcaica grega duas vertentes em tensão. A primeira e mais antiga explicava a prosperidade como resultado automático do nascimento nobre e da obediência aos preceitos divinos e ao senso comum; enquanto que a segunda, mais recente, admitia a existência de um elemento aleatório e que subvertia a vida humana, colocando-a em uma dimensão muito mais misteriosa. A mesma tensão aparece na literatura sapiencial judaica, o que pode se dever a seu contato com a poesia grega mesmo antes do período mais intenso de produção sapiencial judaica, que, grosso modo, coincide com a época de apogeu da cultura helênica em Alexandria, metrópole imprescindível para a aproximação das duas culturas.

\title{
2 A felicidade na vida com moderação
}

A primeira máxima do epigrama anônimo da Antologia palatina que resume os conselhos dos sete sábios para a obtenção da felicidade é a do métron áriston, de Cleobulo de Lindos. Isto é, a moderação assume, para o sábio, o valor de principal fonte da felicidade. Essa mesma frase é atribuída a Demétrio de Faleros (por João Estobeu 3.1.172 e Eustátio 1774.57). Esse pensamento se encontra expresso, com todas as letras, também nos poetas do período arcaico. Teógnis (1.335) declara: pántōn més' árista, "o meio é a melhor de todas as coisas". Píndaro afirma: hépetai d'en hekástōi: métron noềsai dè kairòs áristos, "mas segue, em cada caso: reconhecer a própria medida é a melhor circunstância" (Olímpica 13.47-48). Para o poeta, o homem sábio 


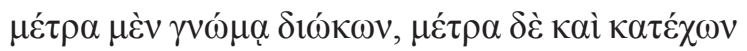

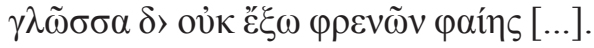

busca, com sabedoria, a moderação e se apega a ela, e sua língua não se afasta de seus pensamentos [...]. (PÍNDARO, Ístmica 6.71-72)

De modo semelhante, na tradição do Certame entre Homero e Hesíodo, Homero supostamente enaltece a máxima do métron áriston:

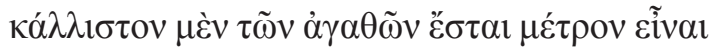

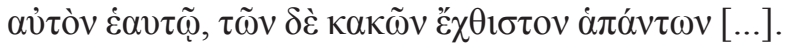

para cada um, ser a medida do bem para si mesmo é excelente; do mal, porém, é a pior de todas as coisas [...].

(Certame entre Homero e Hesíodo, 159).

$\mathrm{Na}$ sabedoria judaica, a posição medial é ocasionalmente enfatizada. Dessa forma, Sophia, a personificação da sabedoria, em Pr. 8.20, afirma: en hodô̂s dikaiosýnēs peripatồ kaì anà méson tríbōn dikaiómatos anastréphomai, "ando nos caminhos da justiça e vivo no meio dos caminhos da ação justa". A sabedoria está, portanto, no meio. Nos Salmos de Salomão (5.17), declara-se: hikanòn tò métrion en dikaiosýnềi kaì en toútōi hè eulogía Kyríou eis plēsmonèn en dikaiosúnēi, "é suficiente a moderação na justiça, e nela está a bênção do Senhor para a satisfação na justiça”. Para Siraque 31.20, "na moderação do estômago está o sono saudável”, hýpnos hygieías epi entérōi metríōi.

\section{A felicidade no conhecimento de si mesmo e de suas circunstâncias}

A segunda máxima no epigrama dos sete sábios (gnốthi seautón, "conhece-te a ti mesmo") também parece informar o conceito de felicidade na literatura sapiencial judaica. Foi atribuída ora a um, ora a outro dos sete sábios, e uma tradição antiga afirma que foram exatamente os sete sábios que a puseram como epígrafe no templo de Delfos (PLATÃO, Protágoras 343b; PAUSÂNIAS, 10.24.1; AUSÔNIO, Ludus septem sapientum 5.7-9). Talvez, na origem, a advertência significasse apenas "percebe com clareza o que queres pedir à divindade", mas obviamente sua fama esteve, desde o início, vinculada a seu potencial 
valor filosófico e psicológico (TOSI, 2000, p. 162). Platão (Alcibiades) e Sêneca (Consolação a Márcia 11.3) a compreenderam como um convite ao conhecimento das características pessoais de um indivíduo; Cícero (Tusculanae disputationes 1.22.52) e Plotino (Enéades 4.3.1.1), como um incitamento à introspecção da alma. Assim, a máxima foi repetida, mais tarde, em um oráculo délfico dado a Sócrates, o que sugere que não é preciso buscar a verdade exteriormente no êxtase. Tudo de que necessitamos está dentro de nós.

Tosi $(2000$, p. 273) associa formalmente o gnôtthi seautón ao kairón gnốthi, "sabe reconhecer a circunstância", atribuída a outro dos sete sábios, Pítaco de Mitilene. Sólon defendia o conceito do kairós áristos ("a oportunidade é a melhor coisa"). Para Teógnis (1.401-402), kairós d'epi pâsin áristos érgmasin antrốpōn ("a oportunidade em relação a todas as ações dos homens é a melhor coisa"). Kairós era representado pelos gregos como uma jovem divindade antropomórfica (daímōn) na ação de afetar a balança (tálanton), fazendo-a pesar para um lado ou para o outro (állote állōs). A felicidade seria, então, a capacidade de agarrar o momento propício (carpe diem), proporcionado pela boa sorte (agathé týkhē). A compreensão de que "a ocasião é a alma da ação" (kairós psykhé prágmatos), posteriormente desenvolvida por Apostólio (9.42), já existia embrionariamente em Píndaro (Pítica 9.78-79): ho dè kairòs homoiós pantòs ékhei koryphán, "a ocasião, porém, tem a primazia em tudo igualmente". Kirkwood (1982, p. 228) define kairós, aqui, como sendo "o exercício da quantidade certa da habilidade certa no tempo certo". Por isso, pode-se dizer que toda realização é kairós. Dessa forma, devese ter consciência da brevidade e transitoriedade da felicidade humana. Por isso, na tradição do certame entre Homero e Hesíodo, encontramos a seguinte admoestação:

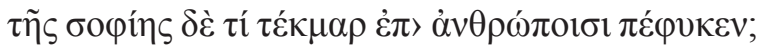

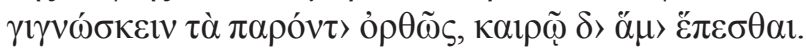

Hesíodo: qual é a marca da sabedoria entre os homens?

Homero: conhecer bem o presente e marchar com a ocasião [kairós].

(Certame entre Homero e Hesíodo, 170). 
Essa ideia de que, para ser feliz, o homem precisa fazer uso pleno das chances que a vida the oferece aparece repetida nos livros sapienciais judaicos. De fato, já no livro canônico dos Salmos, na Septuaginta (LXX), a frase lábō kairón egố, "hei de aproveitar a oportunidade" (Salmo 74.3 ou 75.1), foi atribuída a Deus no contexto do juízo final. No entanto, tanto Eclesiastes quanto Siraque (Eclesiástico) se preocupam com uso que se faz de kairós. De fato, a LXX faz referências constantes à importância de kairós:

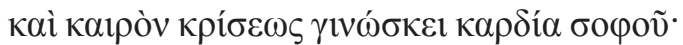

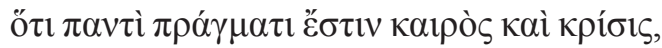

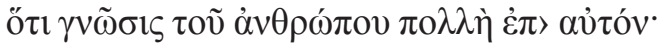

o coração do sábio conhece o momento [kairòn] da decisão porque, para todo propósito, há tempo [kairòs] e decisão, pois é grande o conhecimento que repousa sobre o homem. (Eclesiastes 8.5b-6)

Este texto de Eclesiastes é importante porque se afasta do texto hebraico como o conhecemos e do texto latino da Vulgata. Em ambos, a passagem culmina com a declaração de que é grande a maldade ou aflição do homem. Em Eclesiastes há, em vez disso, um voto de confiança em relação ao conhecimento humano de suas circunstâncias, embora não se possa estar inteiramente seguro se a palavra decisão, nos versos 5 e 6, "não concerne a Deus, à capacidade de avaliação, ao julgamento de valor ou ético de parte do sapiente" (CAMPOS, 1991, p. 180).

O uso de kairós, na LXX, acomoda-se, porém, muito mais a seu sentido comum de 'tempo' ou 'momento' do que, tecnicamente, de 'oportunidade'. Apesar disso, não há como evitar as comparações. Ali, nós nos deparamos inclusive com as consequências de o ser humano não considerar suas oportunidades:

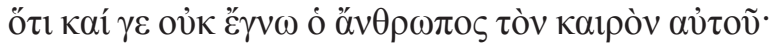

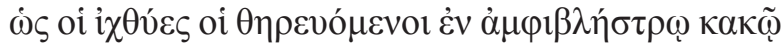

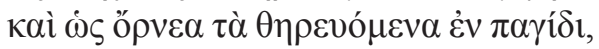

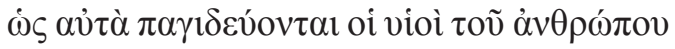

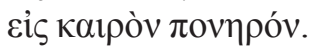


pois o homem não sabe a sua hora [kairòn]; como os peixes que se apanham com a rede traiçoeira, e como os passarinhos que se prendem com o laço, assim se enredam também os filhos dos homens no tempo da calamidade [kairòn ponērón], quando cai de repente sobre eles. (Eclesiastes 9.12)

Em Siraque há uma aproximação maior com a máxima do kairón gnôthi. Em 4.20, temos a recomendação de considerar a ocasião (kairón) e de nos guardar do mal: syntếreson kairòn kaì phúlaxai apò ponēroû. Em 20.6-7, o homem sábio é identificado com aquele "que conhece a ocasião" (eidòs kairón), enquanto "o homem tagarela e tolo" (ho dè lapistè̀s kaì áphrōn) "transgredirá a ocasião" (hyperbếsetai kairón). Assim, também no conceito de felicidade, como derivado da adequada consideração da oportunidade ou ocasião, encontramos o temor de que haja transgressão dos limites aceitáveis impostos pela Divindade. Nesse sentido, conforme sugerido por Jeremias 38.34, kairón gnốthi ("considera a oportunidade") é quase equivalente, na cultura judaica, a gnôthi tòn Kýrion (“conhece ao Senhor”).

\section{A felicidade no controle das paixões, especialmente a ira}

A relação dos poetas arcaicos com as emoções humanas é ambígua. Em alguns momentos, parecem dar inteira vazão a suas paixões, especialmente o amor, chegando a considerar a plena fruição do mesmo como necessária para a obtenção da felicidade. Assim, Simônides (584) indagou: tís gàr hadonâs áter thnatôn bíos potheinòs; ("que vida humana é desejável sem prazer?”). Da mesma forma, Teógnis (2.1335-1336) afirma:

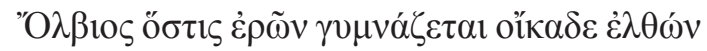

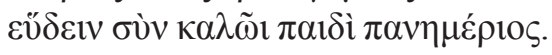

feliz é aquele que se exercita e vai para casa deitar-se com um belo rapaz o resto do dia.

${ }^{2}$ Kairós ponērós é, aqui, a tradução do hebraico 'êth ra 'á, "tempo adverso". 
No entanto, os poetas da Grécia arcaica também consideravam que a felicidade dependia do controle das paixões; por isso, sua recomendação de que a terceira máxima do epigrama dos sete sábios (khólou kratéein, "dominar a ira"), de Periandro de Corinto, fosse obedecida. É preciso controlar as paixões e, por essa razão, mais tarde, os cirenaicos diriam: ékhō, ouk ékhomai, "possuo, mas não sou possuído". De fato, os filósofos gregos de modo geral vão tratar as paixões da alma, especialmente o desejo incontrolável, como enfermidades da alma (KNUUTTILA, 2004).

Segundo Harris (2001, p. 4-5), a Antiguidade clássica via quatro níveis no controle da ira e passou, ao longo dos anos, da ênfase nos três primeiros níveis para a ênfase no último nível: (1) controle da ira na fala e na ação; (2) supressão da ira na fala e na ação; (3) controle dos sentimentos de ira; e (4) supressão dos sentimentos de ira. Esse último nível acabou se tornando o objetivo padrão dos filósofos estoicos, na época do Império Romano, mas não antes. Nessa época, a ideologia helenística do controle da ira e das paixões veio a influenciar profundamente os escritos do Novo Testamento (KELHOFFER, 2007).

No caso da sabedoria judaica, só timidamente encontramos alguma referência à importância dos gozos da vida e do amor como ingredientes necessários para a felicidade. A Sabedoria de Salomão (2.6), representante da "sabedoria consuetudinária", considera que o convite: dê̂te oûn kai apolaúsōmen tồn óntōn agathồn, "vinde, portanto, e desfrutemos das boas coisas que existem", é expresso por aqueles que "não argumentam corretamente" (logisámenoi ouk orthồ, 2.1). No entanto, Siraque (48.11) reflete sobre o valor do prazer no amor:

$\mu \alpha \kappa a ́ p 101$ oi íóv $\tau \varepsilon \varsigma \sigma \varepsilon$

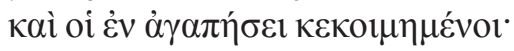

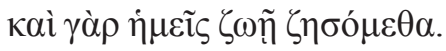

felizes são aqueles que te hão de ver e aqueles que, em amor, adormeceram; pois, de fato, nós hemos de viver a vida.

Com efeito, é o tema do domínio da ira que assume maior importância na Bíblia Hebraica (BALOIAN, 1992). O controle das paixões, de modo geral, perpassa radicalmente o quarto livro dos 
Macabeus, no qual encontramos recomendações explícitas quanto a "dominar as concupiscências", tồn epithymiôn krateîn (4 Mac 2.6); "dominar as paixões mais violentas", tồn biaiotérōn pathôn krateîn (2.15); "dominar a ira", tôิ thymoû krateîn (2.20); "dominar os prazeres e as concupiscências", tồn hēdonōn kaì epithymiồn krateîn (5.23); "dominar os prazeres", tồn hêdonôn krateîn (6.35); e, finalmente, "dominar as paixões da carne", tồn tềs sarkòs pathôn (7.18). A repetida preocupação com a força das emoções, no quarto livro dos Macabeus, mostra como a doutrina grega do khólou kratéein encontrava-se difundida entre os judeus do mundo helenístico.

Embora de modo menos explícito, encontramos uma ansiedade semelhante na literatura sapiencial judaica. Existe, em primeiro lugar, uma preocupação com os danos potenciais do amor: en kállei gynaikòs polloì eplanếthēsan kai ek toútou philía hōs pŷr anakaietai, "na beleza de uma mulher muitos se desviaram e dela o amor se acende como fogo" (Siraque 9.8). Em segundo lugar, exprime-se uma preocupação geral com qualquer tipo de desejo descontrolado: mè epárēis seautòn en boulề psychês sou, "não te deixes levantar no desejo de tua alma" (Siraque 6.2). Em terceiro lugar, mais especificamente, expressa-se o conselho de dominar a ira:

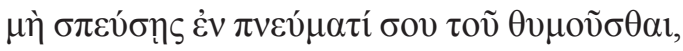

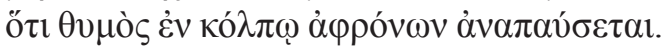

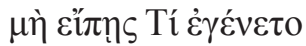

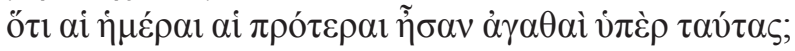

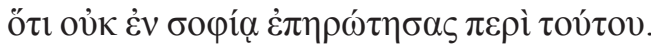

em teu ânimo, não te apresses em irar-te

porque a ira se abriga no seio dos insensatos.

jamais digas: por que foram os dias passados

melhores do que estes?

pois não é sábio perguntar assim.

(Eclesiastes 7.9-10)

Qohélet, no contexto geral da passagem, está pondo em questão o conservadorismo da sabedoria tradicional, ao "desestabilizar a crença em um passado melhor do que o presente", pois, à luz de Eclesiastes 
3.15, a glorificação do passado é "outra forma de impaciência com a vida e suas limitações" (CAMPOS, 1991, p. 160).

No relato da destruição dos primogênitos, filhos dos egípcios, o livro da Sabedoria (18.15-16) conta que o Verbo (ho Lógos) desceu do trono real do céu (ap'ouranôn ek thrónōn basileiôn) e distribuiu morte a todo universo (tà pánta). Os primogênitos, advertidos em sonho quanto à razão de seu extermínio, caíram mortos imediatamente (18.17-19). O poder de destruir do Verbo era tão intenso que mesmo vários dos israelitas tombaram (18.20) e teriam todos perecido, não fora a rápida ação de um homem impoluto (anèr ámemptos) que confrontou a Cólera (thymós), por meio de preces e incensos (18.21). A vitoriosa intercessão de Moisés é, então, comparada à batalha contra a ira:

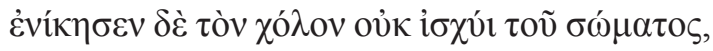

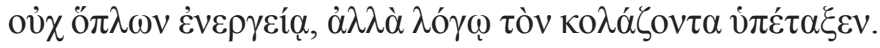

ele venceu a ira, não com a força do corpo nem com o poder das armas, mas prevaleceu contra o verdugo com a palavra. (Sabedoria 18.22).

Assim, a fuga do Egito é alegorizada, primeiramente, como uma libertação da fúria de faraó; em segundo lugar, como a vitória da retórica humana sobre a cólera divina (no Novo Testamento, atribui-se um papel semelhante ao Jesus-Lógos, capaz de nos livrar da "ira vindoura"; cf. ELIAS, 1992); e, finalmente, como a vitória do comedimento do homem pelo controle de si mesmo sobre a própria tendência interior de dar vazão à ira.

\section{A felicidade no respeito aos próprios limites}

Platão (Hiparco 228e) se refere ao fato de que o apotegma do mēdèn ágan ("nada em demasia"), de Pítaco de Mitilene, o quarto no epigrama dos sete sábios, teria sido afixado no frontão do templo de Delfos. Essa máxima, atribuída diferentemente a vários dos sábios gregos, também impregnou profundamente a sabedoria grega. De fato, já aparece em um fragmento de Píndaro (35b Snell-Maehler) e há, em Teógnis (1.401), uma ocorrência qualificada dessa concepção: mēèn 
ágan speúdein, "não ficar ansioso em excesso". O pensamento é expresso, de forma mais completa, por Arquíloco:
$\dot{\alpha} \lambda \lambda \grave{\alpha} \chi \alpha \rho \tau \sigma \tilde{\sigma} \sigma i ́ v \tau \varepsilon \chi \alpha \tilde{i} \rho \varepsilon$

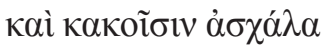

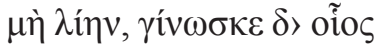

goza as coisas prazerosas,
tolera os males, mas
não em demasia, conhece que
ritmo possui o homem.
(ARQUíLOCO, Fragmento 128.6-7).

A sabedoria judaica prevê a contenção do excesso, pois $h \overline{\mathrm{e}}$ aplēstía engiê̂ héós kholéras, isto é, "o excesso se aproxima da disenteria" (Siraque 37.30). De fato, mesmo o excesso em relação às coisas positivas da dimensão intelectual pode ser prejudicial: hóti en plếthei sophías plêthos gnốseôs, kaì ho prostitheis gnồsin prosthếsei álgēma, "pois na muita sabedoria há muito conhecimento, mas quem aumenta o conhecimento aumentará o sofrimento" (Eclesiastes 1.18). No entanto, as investidas da sabedoria judaica são geralmente dirigidas a dimensões mais mundanas: en plêthei tềs agathōsýnēs eplēthýnthēsan ésthontes autến, "no excesso de bens se multiplicam também os que os devoram" (Eclesiastes 5.10), passagem que nos faz lembrar da Odisseia.

Outra advertência é de que "a voz do tolo está no excesso de palavras", phonè áphronos en plêthei lógōn (Eclesiastes 5.2). Finalmente, ainda se diz: kai ei ebiásthēs en edésmasin, anásta, émeson pórrō kaì anapaúsēi, "se fores forçado a comer excessivamente, levanta, vomita e te sentirás melhor" (Siraque 31.21). Esta é uma compreensão que também é recorrente na modalidade consuetudinária da literatura sapiencial judaica. Ou seja, deve-se sempre evitar o excesso. Por isso, Pr. 25.27 declara: esthíein méli polỳ ou kalón, "não é bom comer muito mel". 


\section{A felicidade no fim da vida}

A questão subjetiva de se avaliar se um homem é ou não feliz transparece na quinta máxima do epigrama dos sete sábios. Para Sólon, é necessário observar antes o fim da vida (térma d'horâin biótoio). Narrativas do famoso encontro entre Sólon e Creso aparecem em um epinício de Baquílides e, mais tarde, em Heródoto (1.32). O mesmo tema é recorrente nas tragédias (ÉSQUILO, Agamêmnon 928-929; SÓFOCLES, Traquínias 1-3; EURÍPIDES, Andrômaca 100-102), nas quais dizer que um homem é feliz pode atrair a inveja dos deuses (phthónos theốn). Os versos finais de Édipo rei fazem referência a essa tradição:

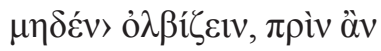

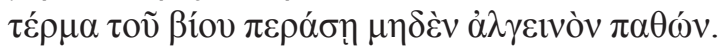

não digas que alguém é feliz antes que

ele tenha transposto o limiar final da vida sem nada sofrer de terrível.

(SÓFOCLES, Édipo rei 1529-1530)

A tradição do certame entre Hesíodo e Homero preserva a concepção de vida epitomizada na máxima do térma d'horâin biótoio, relacionando-a diretamente com o conceito de felicidade:

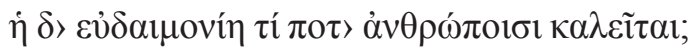

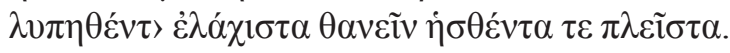

Hesíodo: o que é chamado pelos homens de felicidade?

Homero: a morte após uma vida de mínima tristeza e máximo prazer

(Certame entre Homero e Hesiodo 174-175).

Em íntima relação com a ideia de que não é possível, antes de sua morte, saber se um homem é feliz ou não, está a tradição de que é melhor não ter nascido. No mito que relata a captura de Sileno, companheiro de Baco, por Midas, temos a indicação de que o melhor é não nascer (to $m \bar{e}$ genésthai) e, depois de ter nascido, o melhor é morrer o mais depressa possível. Na Ilíada há uma referência a essa tradição, embora talvez 
seja o caso de uma interpolação. A máxima reaparece no Certame entre Homero e Hesíodo, em Baquílides (Epinício 5.160-164), no Museion, de Alcídamas, um dos discípulos de Górgias, e em Teógnis (1.425-428):

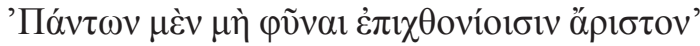

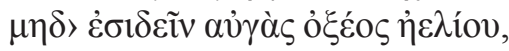

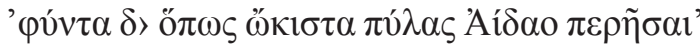

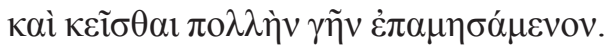
para os habitantes da terra, a melhor de todas as coisas é não ter nascido nem ter contemplado os raios do sol agudo, porém, ao nascer, atravessar o mais depressa as portas do Hades e jazer onde se amontoou bastante terra sobre si mesmo.

Esse dístico elegíaco de Teógnis sugere que essa tradição já se encontrava amplamente difundida no século VI. Um epinício de Baquílides em homenagem a Híeron de Siracusa por sua vitória com um único cavalo, em Olímpia, em 476 a.C., apresenta a mesma concepção:

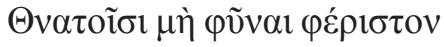
$\mu \eta \delta$ '

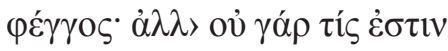
$\pi \rho \tilde{\alpha} \xi 1 \zeta \tau \alpha \dot{\delta} \delta \varepsilon \mu \nu \rho \mu \varepsilon_{\varepsilon} v o 1 \varsigma$,

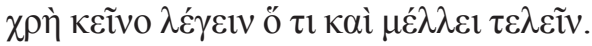
aos mortais é melhor não ter nascido
nem ter contemplado a luz do sol;
mas não há benefício algum em lamentar isso;
deve-se falar do que se pode realizar.
(BAQUÍLIDES, Epinicio 5.160-164)

Contrariando a sabedoria consuetudinária, a influência da sabedoria subversiva que, segundo minha proposta, pode derivar da tradição poética grega arcaica, inclui o tema da desejabilidade da morte, que aparece em Eclesiastes 7.1-2: 


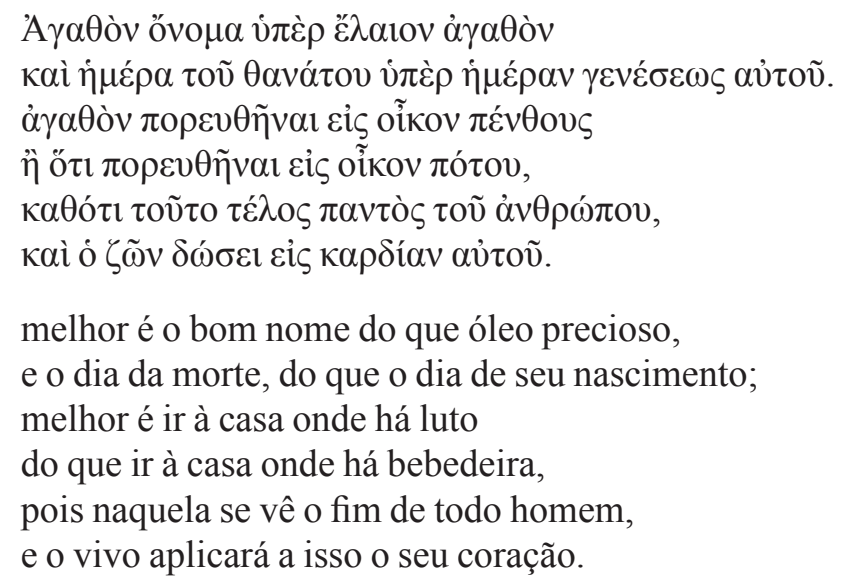

Assim, com a frustração da expectativa no plano do conteúdo e sutis deslocamentos de perspectiva, Qohélet vai patenteando os defeitos do pensamento judaico tradicional. Aliás, esse é o dilema experimentado por Jó diante das catástrofes que se abateram sobre si e a família. Jó rejeita a sabedoria consuetudinária representada por Elifaz, Bildade e Zofar, os três amigos que tentam consolá-lo com a ideia de que, por certo, Jó havia cometido algum engano, o que o teria levado a perder a felicidade. Sua resposta é amaldiçoar o dia do próprio nascimento (Jó 3.1-14; 10.18-22).

$\mathrm{O}$ apotegma de que é melhor não ter visto a luz do sol se encontra em uma passagem na qual Qohélet estabelece a comparação entre um hipotético homem longevo, com dois mil anos de idade, e um natimorto:

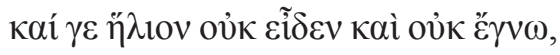

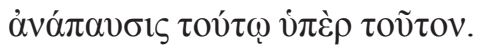

nem viu o sol nem o conheceu; há mais descanso para este do que para outro (Eclesiastes 6:5)

Para o Qohélet, portanto, as ações do homem não podem contribuir, de forma consistente, para a sua felicidade.

A ideia da morte como momento derradeiro em que se avalia se um homem foi feliz ou não se encontra mais plenamente expressa em Siraque (7.36 e 11.28): 


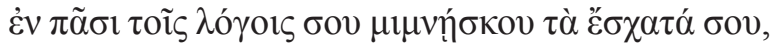

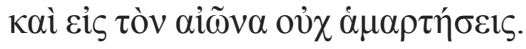

em todas as tuas palavras lembra-te de teu fim

e, para sempre, nunca pecarás.

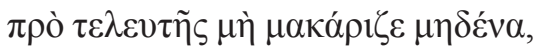

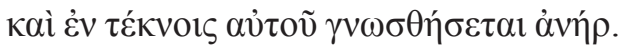

a ninguém louves antes da morte;

é pelos filhos que se conhece o homem.

Apesar de difundida na literatura sapiencial, a ideia do benefício da morte não aparece isenta de protestos. O livro não canônico da Sabedoria de Salomão (1.16), mais afeito às máximas da sabedoria consuetudinária, reclama que somente os ímpios (asebeîs) invocam a morte, considerando-a amiga (phílos). Para ele (1.17), ouk éstin íasis en teleutềi anthrốpou, "não há remédio no fim do homem". Apesar disso, considerando a perspectiva de vida após a morte, reconhece que pelo menos o homem íntegro "bendiz o fim dos justos", makarízei éskhata dikaíōn (2.16).

\section{A felicidade no esquivar-se à fiança}

A tradição mais antiga da poesia grega, especialmente em sua vertente épica, atribuía características nobres à disposição de servir de fiador àqueles que necessitavam de um. Assim, no Canto VIII da Odisseia, Posídon se voluntaria como fiador de Ares por seu débito para com Hefesto em função de tê-lo traído com Afrodite. No entanto, assim como ocorreu com o topos da felicidade como possível de ser avaliada apenas no dia da morte, essa tradição evoluiu para uma vertente mais subversiva. A máxima do engyēn pheúgein ("esquivar-se à fiança”), geralmente atribuída a Tales de Mileto, é considerada por Pellizer (2009) como indigna da estatura intelectual do grande pensador. No entanto, apesar de seu caráter essencialmente prático e mundano, é compreensível por que os sábios gregos consideravam esse apotegma como fundamental para a obtenção da felicidade. 
Essa tradição se encontra presente, com relativa abundância, nas duas vertentes da literatura sapiencial da LXX, onde é apresentada como uma forma de impedir que o homem em busca da felicidade perca os elementos mais essenciais para a satisfação de suas necessidades:

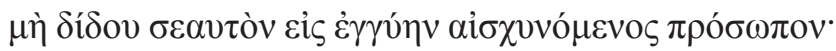

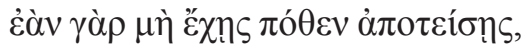

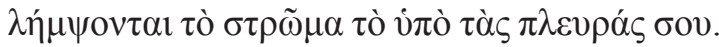

não te ofereças para fiador, envergonhando o próprio rosto;

pois, se não tens com que pagar, será tirada

a cama de debaixo das tuas costas.

(Pr. 22.26-27)

De fato, para o autor de Provérbios, ser fiador é um indício de estultícia:

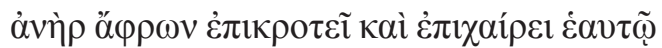

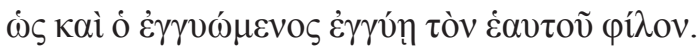

o homem falto de entendimento compromete-se, ficando por fiador de seu amigo.

(Pr. 17.18)

Além disso, a consideração dos efeitos da fiança varia desde um desconforto passageiro (Siraque 8.13) até a total desintegração econômica de um indivíduo (Pr. 22.26-27). De fato, a disposição para se tornar fiador é ainda considerada mais ofensiva se motivada pela esperança de ganho fácil. Siraque (29.17-19) compara essa atitude com a de um criminoso:

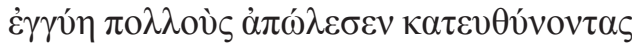

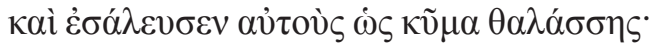

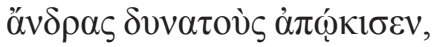

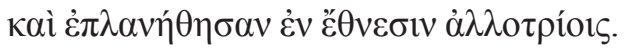

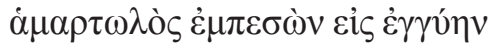

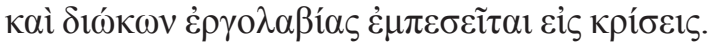

a fiança já arruinou a muitos que eram prósperos, e os submergiu como uma onda do mar; ela já tirou homens poderosos de sua casa 
e os fez peregrinar entre povos estrangeiros; um pecador com pressa de ser fiador e que busca o lucro se apressa em receber a condenação.

Esta é uma leitura bem diferente da que se encontra na Vulgata, que condena não o fiador, mas o que transgride os mandamentos de Deus (peccator transgrediens mandata Domini).

A sabedoria judaica ata a questão do fracasso do fiador a uma inadequada consideração de kairós:

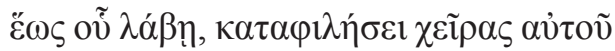

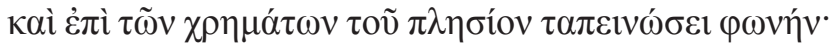

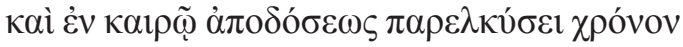

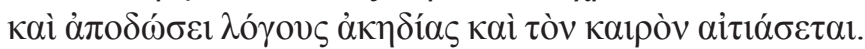

até conseguir algo, beijará suas mãos e abaixará a voz

para falar da riqueza de seu vizinho;

mas na ocasião [kairós] do pagamento,

arrastará o tempo e pagará com palavras de acomodação,

e porá a culpa nas circunstâncias [kairós].

(Siraque 29.5)

\section{A felicidade na saúde}

A máxima de Bias de Priene do toùs pléonas kakious constata o fato de que a maioria dos homens é em si mesma má. Não se trata, aqui, de uma recomendação voltada para a felicidade humana, mas de uma expressão pessimista de que haverá obstáculos para a sua obtenção. Por essa razão e dada a prevalência do apotegma hygiaínein mèn áriston andrì thnētồ, "a saúde é a melhor coisa para o homem mortal" (SIMÔNIDES 651), em vez de abordar a máxima incluída no epigrama dos sete sábios, seria conveniente tratar da concepção do hygiés anếr ou "homem saudável". O ideal de felicidade aristocrática geralmente se voltava para o entretenimento de hóspedes, o cultivo de uma boa reputação e a fruição da saúde, como se percebe nos versos finais de Trabalhos e dias: 


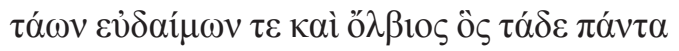

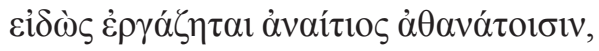

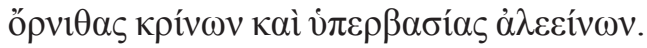

feliz e afortunado é aquele que, sabendo tudo isso,

"obra" sem ofender os imortais,

consultando as aves e evitando as transgressões.

(HESÍODO, Trabalhos e dias 826-828).

Assim, até a higiene do aristocrata tem importância para garantir sua felicidade.

Para Simônides (604), oudè kalâs sophías estìn kháris ei mé tis ékhei semnàn hygieian ("não há prazer mesmo na linda sabedoria a não ser que o homem possua a saúde santa"). Não se deve pensar, porém, que a felicidade do "homem saudável" dependa exclusivamente de suas condições físicas. A expressão é tomada em um sentido muito mais amplo, que envolve o bem-estar da sociedade como um todo. O lado subversivo da compreensão poética dos gregos em relação à felicidade aponta para o "homem saudável" como sendo aquele que se exime de comportamento vergonhoso:

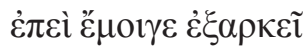

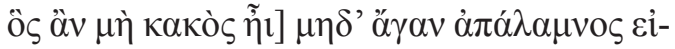

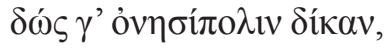

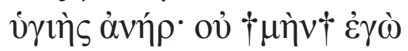

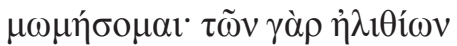

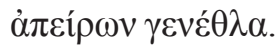

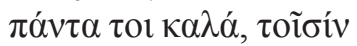

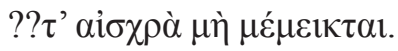

Basta para mim que alguém não seja mau, nem inexperiente demais, conhecendo a justiça que é útil à sociedade, homem saudável; eu não o censurarei (pois não sou amante da censura nem há limites para a estirpe dos idiotas). Belas são todas as coisas às quais não se misturam os atos vergonhosos! (SIMÔNIDES, Fragmento 37). 
Dentro da concepção de que "a sociedade educa o homem" (pólis ándra didáskei, fragmento 15), Simônides revela que o "homem saudável" é aquele que poupa a sociedade de sua incivilidade.

No contexto da sabedoria judaica, o apreço à saúde sob o prisma da sanidade social permeia o livro de Siraque. De modo surpreendentemente pouco aristocrático, o autor a considera superior mesmo à posse das riquezas:

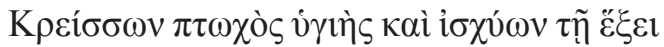

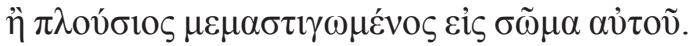

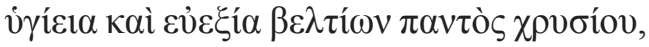

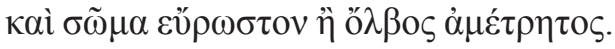

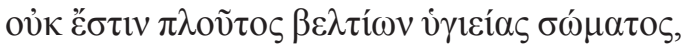

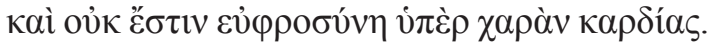

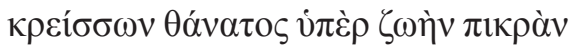

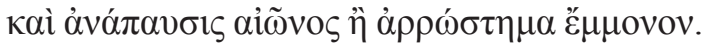

É melhor ser pobre, mas saudável e cheio de vigor, do que rico, mas atormentado quanto ao corpo; a saúde e a força são melhores do que qualquer ouro, um corpo robusto, do que riqueza imensurável; não existe riqueza melhor do que a saúde do corpo e não há gozo além da alegria do coração; é melhor a morte do que a vida miserável e o descanso eterno, do que a doença crônica! (Siraque 30.14-16)

Em vez de áriston (ou lôiston), lugar-comum da poesia arcaica grega sobre a felicidade, encontramos as formas kreíssōn e beltíōn, permuta sugestiva de superlativo e comparativo. Cleobulo de Lindos, um dos sete sábios, dizia métron áriston ("a moderação é a melhor coisa") e o famoso epigrama de Delos anunciava lồiston d'hygiainein ("o melhor é ter saúde"). Siraque enaltece o "corpo robusto" (sồma eúrōston) e a "saúde do corpo" (hygieía sốmatos), mas acrescenta sua superioridade mesmo em relação aos bens materiais (ólbos amétrētos).

A preocupação com a saúde se tornou tão obsessiva que, para os judeus helenizados, a saudação comum deixou de ser shalom para tornar- 
se hygiaínein, como percebemos em diversas passagens dos Macabeus, das quais 2 Mac. 9.19 e 11:28 são apenas exemplos. Para os gregos, a expressão eudaimonía ("felicidade") pressupunha o favor dos deuses. A literatura sapiencial judaica evita a palavra. No entanto, ao empregar o termo equivalente, makárioi ("venturosos"), mantém certa preocupação com a hyperbasía (ou "transgressão"): makárioi hoi phoboúmenoi ton kúrion, "venturosos são os que temem o Senhor" (Salmos de Salomão 4:23). O conceito de saúde também se faz presente, nesse sentido, em Siraque. É preciso ter saúde para não ofender a Deus, deixando de lhe atribuir o louvor que lhe é devido: zồn kai hygiếs ainései tòn kúrion, "vivo e saudável, louvará o Senhor" (Siraque 17:26). Transgressão tem, porém, o sentido muito mais restrito de ofensa a Deus.

\section{Considerações finais}

Ocorreu na antiga poesia grega uma espécie de amadurecimento na compreensão que os poetas tinham das causas da felicidade humana e em sua apreciação da prosperidade. Isso é percebido, por exemplo, numa comparação entre o tratamento dado pela poesia épica a Alcínoo, o majestoso anfitrião do Canto VIII da Odisseia, e o tratamento dado, mais tarde a Creso, rei da Lídia. Diante da opulência de Creso, Sólon observa que ninguém pode ser considerado feliz antes de morrer. Em relação a isso, Siraque (10.10) diria: basileùs sémeron kaì aúrion teleutếsei, "hoje rei, amanhã morrerá". De fato, o mesmo movimento de uma sabedoria consuetudinária para uma sabedoria subversiva parece ocorrer também no recorte estudado da literatura sapiencial judaica, pois se percebe uma evolução, nessas dimensões, do conceito de felicidade do Pentateuco e do livro de Provérbios para o de Jó, Eclesiastes e Siraque. No entanto, esse movimento não é inteiramente abrangente, pois a velha noção da felicidade como resultado direto de determinadas virtudes, "do que as quais nada é mais útil na vida para os homens" (hồn chrēsimôtteron oudén estin en biōi anthrốpois, Sabedoria de Salomão 8.7), e oriunda exclusivamente do beneplácito divino, persiste no livro da Sabedoria de Salomão. Para o autor, no viver sábio não há dor, "mas somente prazer e alegria” (allà euphrosúnēn kaì kharán, 8.16). Jó e Eclesiastes 
são os principais representantes da sabedoria subversiva na literatura sapiencial judaica, pois, em Siraque, há, às vezes, um retorno à sabedoria consuetudinária: mè poíei kaká, kai ou mè se katalábēi kakón, "não faças o mal e o mal não se apoderará de ti” (7.1).

No caso de uma sabedoria subversiva possivelmente derivada das influências helenísticas, não existe, porém, fórmula perfeita que garanta a felicidade: pân hò eàn epachthềi soi déxai, kaì en allágmasin tapeinốseṓs sou makrothúmēson, "aceita tudo o que te suceder e, nas incertezas de tua humilhação, tem paciência” (Siraque 2.4). O que há são diretrizes gerais que podem oferecer ao homem mais chances de alcançar seu sonho de felicidade. Por isso, ao se referir à visão romântica de que determinados comportamentos, por si só, garantem a bem-aventurança terrena, Jó declara:

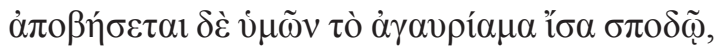
$\tau$ ò $\delta \dot{\varepsilon} \sigma \tilde{\omega} \mu \alpha \pi \dot{n} \lambda$ ivov.

a vossa insolência se tornará como cinza;

o vosso corpo [= defesa?], como barro (Jó 13.12)

Uma comparação ainda que superficial com o Pentateuco e os livros proféticos da Bíblia Hebraica sugere que o judaísmo sempre teve mais afinidade com os preceitos da sabedoria convencional. A vertente predominante da literatura sapiencial judaica é aquela expressa nos livros de Provérbios, Eclesiástico, Sabedoria e Salmos de Salomão. São os livros de Jó e Eclesiastes que requerem explicação devido a sua filiação aos apotegmas da sabedoria subversiva, incomum nos círculos judaicos. A conclusão de que essa vertente tenha se originado do contato com os gregos tem algumas vantagens explanatórias: dá algum tipo de suporte à suposição tão comum entre os historiadores do judaísmo de que os processos de helenização de Israel tiveram início bem antes do século III, período geralmente apontado como época do desencadeamento de tais processos, explica o vivo interesse de seus autores pela literatura estrangeira, conforme já notou Hartley (1988), e propõe uma solução pelo menos provisória para a misteriosa incursão de uma vertente não consuetudinária na literatura sapiencial judaica. 


\section{Referências}

ANDERSEN, F. I. Job: An Introduction and Commentary. Downers Grove, ILL.: IVP Academic, 2015.

BALOIAN, B. E. Anger in the Old Testament. New York: Peter Lang, 1992.

BORG, M. J. Reading the Bible Again for the First Time: Taking the Bible Seriously But Not Literally. San Francisco: Harper, 2001.

BRYCE, G. E. A Legacy of Wisdom: the Egyptian Contribution to the Wisdom of Israel. Lewisburg, PA: Bucknell, 1979.

CAMPOS, H. Qohélet, O-que-sabe: Eclesiastes, poema sapiencial. São Paulo: Perspectiva, 1991.

DOYLE, R. E. Olbos, koros, hybris and atê from Hesiod to Aeschylus. Traditio, New York, v. 26, p. 293-303, 1970.

ELIAS, J. W. "Jesus Who Delivers Us from the Wrath to Come" (1 Thess 1:10): Apocalyptic and Peace in the Thessalonian Correspondence. $S B L$ Seminar Papers, Atlanta, v. 31, p. 21-132, 1992.

FOHRER, G. Zur Vorgeschichte und Komposition des Buches Hiob. Veterum Testamentum, Leiden, v. 6, f. 3, p. 250-251, 1956.

GESE, H. Wisdom Literature in the Persian Period. In: DAVIES, W. D.; FINKELSTEIN, L. (Ed.). Cambridge History of Judaism: the Persian Period. Cambridge: Cambridge University Press, 2003. v. 1, p. 189-218.

GORDIS, R. The Book of God and Man. Chicago; London: University of Chicago Press, 1978.

HARRIS, W. V. Restraining Rage: the Ideology of Anger Control in Classical Antiquity. Cambridge: Cambridge University Press, 2001.

HARTLEY, J. E. The New International Commentary on the Old Testament: the Book of Job. Grand Rapids: Eerdmans, 1988.

HEINISCH, P. Die griechische Philosophie im Buche der Weisheit. Münster: Aschendorffsche Buchhandlung, 1908.

KELHOFFER, J. A. Suppressing Anger in Early Christianity: Examples from the Pauline Tradition. Greek, Roman, and Byzantine Studies, Durham, v. 47, p. 307-325, 2007. 
KIRKWOOD, G. Selections from Pindar. Chico, CA: Scholars Press, 1982.

KNUUTTILA, S. Emotions in Ancient and Medieval Philosophy. Oxford: Oxford University Press, 2004.

LANGE, S. The Wisdom of Solomon and Plato. Journal of Biblical Literature, Atlanta, v. 55, n. 4, p. 293-302, 1936.

MOMIGLIANO, A. Alien Wisdoms: the Limits of Hellenization. Cambridge: Cambridge University Press, 1971.

PELLIZER, E. Felicidade na literatura grega. Pós-graduação em Estudos Literários. Belo Horizonte: Universidade Federal de Minas Gerais, 2009. Notas de aula.

TERRIEN, Samuel L. Job, Poet of Existence. Eugene, OR.: Wipf \& Stock, 2004.

TOSI, R. Dicionário de sentenças latinas e gregas. Tradução de Ivone Castilho Benedetti. São Paulo: Martins Fontes, 2000.

Recebido em: 4 de março de 2018. Aprovado em: 3 de maio de 2018. 